\section{Kuzmin 0 . Melnyk 0., Zhuk $\mathbf{L}$.}

\title{
FORMATION OF DIAGNOSTICS INDICATOR BASE OF THE UNIVERSITY SCIENTIFIC ACTIVITY SYSTEM
}

Запропоновано та обгрунтовано сукупність індикаторів для діагностування стану системи наукової діяльності закладів вищої освіти. Усі індикатори згруповано за підсистемами, які відображають найважливіші напрями провадження наукової діяльності. Показано, що найбільш репрезентативними індикаторами є показники ресурсного забезпечення наукової діяльності, ї̈ результативності, а також показники, які характеризують стійкість, адаптивність та надійність системи. Для кожного з обраних індикаторів встановлено нормативно-критеріальні значення.

Ключові слова: діагностування стану системи наукової діяльності університету, індикатори для діагностування, заклади вищої освіти.

\section{Introduction}

Diagnostics is considered as a process of recognizing and determining positive or negative (crisis) trends in the activity of an enterprise on the basis of identified local changes, established dependencies, and indicators that have a particularly great influence on the efficiency of the enterprise's activity [1]. The main purpose of the diagnosis is establishment of the actual state of the enterprise and its development trends for the timely development and adoption of sound management decisions [2].

Carrying out of diagnostics of separate directions of activity, including scientific activity as one of the priority, today acquires special significance for higher educational institutions (HEI), which are in a highly competitive environment in the market of educational and scientific services. The urgency of the problem is exacerbated by the presence of such threats as the instability of economic processes, the outflow of young people and highly qualified personnel abroad or into the more highly paid sectors of the Ukrainian economy, the decline in the prestige of scientific and scientific-pedagogical activity, etc. [3, 4].

\section{The object of research and its technological audit}

The object of research is the indicators for the state diagnosis of the HEI scientific activity system, in particular the university.

Diagnosing the state of the HEI scientific research system involves researching the main aspects of scientific activity, identifying chances and threats to its production, and forming an information base for making managerial decisions. From an organizational point of view, diagnostics is the use of a set of methods and techniques for determining the effectiveness and efficiency of the production of HEI scientific activity, the compliance with the strategic tasks. The quality and reliability of diagnostics largely depends on the toolkit, first of all on the correctness and correctness of the choice of indicators that most fully and comprehensively characterized the state of the system of scientific activity. Thus, the selection of the indicator base, which determines the quality of the information received and results in the effectiveness of management decisions, is a dominant issue in the process of diagnosing the state of the HEI scientific research system.

\section{The aim and objectives of research}

The aim of research is formation of an indicator base for diagnosing the state of the HEI scientific activity system. To achieve the stated aim of research, it is necessary to perform the following tasks:

1. Selection of indicators and the rationale for their use in diagnosing the state of the HEI scientific activity system.

2. The wording of proposals to supplement the list of indicators of reporting on scientific and scientific and technical activities, is annually formed by the HEI and is submitted to the Ministry of Education and Science of Ukraine.

\section{Research of existing solutions of the problem}

The publication of many scientists [4-9] is devoted to the study of the methodological foundations and tools of enterprise diagnostics. The authors of [10-14] with the basic principles of the formation of a system of performance indicators of enterprises include:

- link indicators with the strategy of enterprise development in the long term;

- relevance (indicators should clearly reflect the main objective and the development objectives of the enterprise subject to it);

- integrity of the coverage of all areas of the enterprise and all hierarchical levels of management, the need to take into account both financial and non-financial indicators;

- integration into the enterprise management system;

- information transparency, visibility and accessibility of indicators; 
- mutual consistency, interdependence and balance of indicators;

- formal representation and quantitative expression of indicator values;

- limited number of indicators (no more than 25).

In [15] it is noted that the system of indicators of the state of the enterprise is chosen so as to avoid duplication of information by different indicators, that is, each indicator should characterize a new phenomenon in its activity.

The authors of [16] emphasize the fact that in the formation of criteria and indicators for monitoring and diagnosing the HEI activity, it is necessary to focus primarily on the principles of the system approach. For this purpose, the indicators are distributed according to three conditional groups: criteria and indicators of the security, efficiency and effectiveness of the HEI operation. In [17] criteria (mandatory, comparative and bonus) are summarized for granting and confirming the status of the national HEI. In [18] four criteria are determined, according to which the HEI state certification will be carried out in the part of their implementation of scientific (scientific and technical) activities:

- provision of scientific and scientific-pedagogical personnel (quantitative composition, level of qualification of scientists);

- availability of modern material and technical base used in the implementation of scientific research and development;

- quality of scientific and scientific and technical results on the basis of expert evaluation, taking into account the level of publication activity, in particular scientometric indicators used in the international examination system;

- active involvement of state budget funds and customer funds in selected scientific areas (annual increases in the volume of funding of scientific (scientific and technical) works from general and special funds of the state budget).

At the same time, the authors of $[5,6,19]$ note that not a single conceptual model of indicators is able to cover absolutely all aspects of diagnosing the HEI activity.

\section{Methods of research}

To solve the set tasks, methods of expert evaluation, analysis and synthesis, logical generalization, comparative comparison are used.

\section{Research results}

Based on the generalization of the existing methodological experience in diagnosing enterprises and taking into account the specifics of the HEI activity, a set of basic indicators for diagnosing the state of the HEI scientific activity system is proposed and justified (Table 1). All indicators are grouped by subsystems, which reflect the most important areas of scientific activity:

- conducting scientific research (20 indicators);

- training of highly qualified scientific personnel (11 indicators);

- ensuring the creative activity of participants in the educational process (3 indicators);

- use of scientific results obtained in the educational process (3 indicators).
Indicators are formed taking into account the methodical principles specified in [9-12]: indicators of resource support of scientific activity, its effectiveness, as well as indicators reflecting the stability, adaptability and reliability of the system of scientific activity are selected.

Selected indicators of resource provision are shown in Table 1 and reflect the personnel potential of the university, the scientific infrastructure, financial resources, which are aimed at carrying out scientific research, material and technical and information support. Performance indicators take into account scientific, innovative, financial and economic performance, as well as the effectiveness of international cooperation.

Indicators reflecting the financial stability of the system, the availability and effectiveness of the system of motivation, the availability of HEI staff scientists and young scientists are proposed indicators of the sustainability, adaptability and reliability of the system of scientific activity.

The sources of information for the proposed indicators are statistical survey data in accordance with the approved forms [20-22], and «Indicators of scientific and technical activities of the HEI», which are submitted annually to the Ministry of Education and Science of Ukraine [23]. In addition, such sources can be data from the monitoring case of the national HEI in support of the national status [17].

For each of the selected indicators, the standard-criteria values are established. These values are determined taking into account such methodological approaches to the assessment of diagnostic parameters [24]:

- dynamic analysis (provides for the study of indicators in the dynamics);

- comparative analysis (it involves comparing the actual value of the indicator with the industry average or with the average for a group of similar enterprises);

- reference analysis (comparison of the actual value of the indicator with the reference value, which is defined as the allowable (the critical limit of its change).

It is important to note that in order to obtain an impartial diagnostic analysis, indicators for diagnosis should be calculated over a period of not less than three years.

The proposed set of indicators (Table 1) forms the basis for further interpretation of the state of the HEI scientific activity system, obtaining a holistic view of the problems, shortcomings and threats to the implementation of scientific activity, and making informed management decisions.

Despite the information availability of the proposed indicators, they can be used in the rapid diagnosis of the state of the HEI scientific activity system. To conduct a more thorough, comprehensive diagnosis, which can be carried out by specialists of the HEI, or on its initiative by invited specialists, it is necessary to formulate a list of additional indicators that can be obtained on the basis of detailed study of the HEI normative documents and the results of special surveys. At the same time, it is expedient and necessary to use not only quantitative indicators, but also qualitative ones. The formation of such indicators for comprehensive diagnosis will be the subject of further research. 
Indicators of diagnostics of the HEI scientific activity system*

\begin{tabular}{|c|c|c|}
\hline Indicators & Normative-criteria value & Justification of the indicator choice and its content \\
\hline 1 & 2 & 3 \\
\hline \multicolumn{3}{|l|}{ 1. "Conducting of scientific research" subsystem } \\
\hline $\begin{array}{l}\text { 1.1. The number of full-time employees - doctors } \\
\text { of sciences and candidates of sciences in the total } \\
\text { number of full-time scientific and scientific-pedagogical } \\
\text { workers (55PW) }\end{array}$ & [0.6-0.9] & $\begin{array}{l}\text { Reflects the share of highly qualified personnel in the total number of } \\
\text { employees involved in scientific research. The high level of availability } \\
\text { of such personnel leads to the HEI scientific effectiveness, positively } \\
\text { affects the quality of scientific and educational services, the increase } \\
\text { in the volume of feasibility of scientific and technological products }\end{array}$ \\
\hline $\begin{array}{l}\text { 1.2. The number of young scientists (candidates of } \\
\text { science under the age of } 35 \text { and doctors of science } \\
\text { under the age of } 40 \text { ) - full-time employees in the } \\
\text { total number of 5SPWs }\end{array}$ & {$[0.2-0.5]$} & $\begin{array}{l}\text { Testifies to the degree of effectiveness of the SSPWs motivation system, } \\
\text { which is usually based on such external stimuli as: } \\
\text { - a decent level of wages; } \\
\text { - developed material and technical base for conducting research; } \\
\text { - ability to study abroad; } \\
\text { - opportunity for career growth; } \\
\text { - favorable socio-psychological climate; } \\
\text { - comfortable working conditions; } \\
\text { - the authority and high reputation of the HEI. } \\
\text { In HEI, a certain balance between teachers of different ages, experience } \\
\text { and scientific merits is important. The indicator reflects the sustainability } \\
\text { of the HEI scientific activity system }\end{array}$ \\
\hline $\begin{array}{l}\text { 1.3. Number of full-time scientific workers in the total } \\
\text { number of established SSPWs }\end{array}$ & {$[0.1-0.3]$} & $\begin{array}{l}\text { A high proportion of full-time scientific workers is observed, as a rule, } \\
\text { in the presence of constant funding (by a general and/or special fund) } \\
\text { and confirms the relevance of the research work being carried out. } \\
\text { The presence of full-time scientific workers testifies to the continuity } \\
\text { of research on a certain scientific topic. The indicator indicates the } \\
\text { stability of the HEI scientific activity system }\end{array}$ \\
\hline $\begin{array}{l}\text { 1.4. The number of full-time 5SPWs and doctoral } \\
\text { students, marked by state awards of Ukraine, as well as } \\
\text { young scientists who received prizes, grants, scholar- } \\
\text { ships of the President of Ukraine, the Verkhovna Rada } \\
\text { of Ukraine, the Cabinet of Ministers of Ukraine, in the } \\
\text { total number of full-time SSPWs, doctoral candidates, } \\
\text { post-graduate students }\end{array}$ & $\begin{array}{l}>0, \\
\text { increase }\end{array}$ & $\begin{array}{l}\text { Testifies to the high level of scientific achievements of the 55PW, } \\
\text { doctoral and post-graduate students, their relevance and recognition } \\
\text { at the national level. Demonstrates the scientific activity of the HEI } \\
\text { and young scientists }\end{array}$ \\
\hline $\begin{array}{l}\text { 1.5. The number of full-time SSPWs that have been } \\
\text { trained, conducted training sessions in foreign research } \\
\text { institutions (scientific institutions) (P10), in the total } \\
\text { number of SSPWs }\end{array}$ & increase & $\begin{array}{l}\text { Reflects the level of HEI academic mobility. Testifies to the level of } \\
\text { development of scientific contacts, integration into the international } \\
\text { educational and scientific space. Demonstrates the level of HEI quali- } \\
\text { fication in terms of knowledge of foreign languages }\end{array}$ \\
\hline $\begin{array}{l}\text { 1.6. The share of the volume of the additional wage } \\
\text { fund and other incentive and compensation payments } \\
\text { in the total amount of the wage fund (basic wage fund, } \\
\text { additional wage fund, other incentive and compensa- } \\
\text { tion payments }\end{array}$ & {$[0.3-0.5]$} & $\begin{array}{l}\text { Shows the presence of a system for assessing the professional (in } \\
\text { particular, scientific) effectiveness of the SSPW and providing conditions } \\
\text { for their material encouragement in the HEI. The increase in the share } \\
\text { of additional wages and other incentive and compensation payments } \\
\text { in total wages is an indicator of the high achievements of the SSPW }\end{array}$ \\
\hline $\begin{array}{l}\text { 1.7. The volume of all types of costs for the imple- } \\
\text { mentation of scientific research and development in } \\
\text { the HEI total budget }\end{array}$ & {$[0.1-0.25]$} & $\begin{array}{l}\text { Demonstrates the role of scientific research in the main areas of the } \\
\text { HEI activity (educational, scientific and innovative). There is a priori } \\
\text { low because of the failure to comply with the provisions of the Law of } \\
\text { Ukraine "Dn Higher Education» in terms of ensuring budgetary financing } \\
\text { of the HEI. According to Art. } 29 \text { of the Law [25], the national HEI has } \\
\text { the right to receive on a priority basis the funds provided by the state } \\
\text { budget for the implementation of scientific and technological activities } \\
\text { in the amount of not less than } 10 \text { percent of the state budget allocated } \\
\text { to its maintenance }\end{array}$ \\
\hline $\begin{array}{l}\text { 1.8. The ratio between the volume of financial receipts } \\
\text { to a special fund (business agreements, grants from } \\
\text { the fund for basic research, international projects, etc.) } \\
\text { and the general fund of the state budget }\end{array}$ & {$[0.7-1.5]$} & $\begin{array}{l}\text { Reflects the efficiency of using funds allocated from the general fund } \\
\text { of the state budget for the performance of scientific research and } \\
\text { development. There is an indicator of the commercialization of the } \\
\text { results of scientific research, the introduction of the results of the } \\
\text { implementation of fundamental and applied scientific research in va- } \\
\text { rious segments of the national and global markets. Demonstrates the } \\
\text { stability of the system of scientific activity. The indicator is informative } \\
\text { in the presence of financial receipts in both the special and general } \\
\text { funds of the state budget }\end{array}$ \\
\hline $\begin{array}{l}\text { 1.9. The volume of financial contributions to the gene- } \\
\text { ral fund in terms of the number of full-time SSPWs }\end{array}$ & $\begin{array}{l}\text { increase, } \\
\text { orientation to the maximum } \\
\text { value among the HEIs }\end{array}$ & $\begin{array}{l}\text { Reflects the relevance of the subject matter of HEI scientific research } \\
\text { and its correspondence to the priority areas of the development of } \\
\text { science and technology in Ukraine. Reflects the effectiveness of scientific } \\
\text { groups (scientific schools), which take part in the competition of scientific } \\
\text { research, funded by the Ministry of Education and Science of Ukraine. } \\
\text { There is also an indicator of the stability and reliability of the system }\end{array}$ \\
\hline $\begin{array}{l}\text { 1.10. The volume of financial receipts to a special fund } \\
\text { in terms of the number of full-time SSPWs }\end{array}$ & $\begin{array}{l}\text { increase, } \\
\text { orientation to the maximum } \\
\text { value among the HEIs }\end{array}$ & $\begin{array}{l}\text { It is one of the most important indicators of the scientific activity and } \\
\text { effectiveness of the HEI, as well as the effectiveness of the marketing } \\
\text { activities of the HEI. Demonstrates the relevance of scientific research, } \\
\text { their relevance at the international, national and regional levels }\end{array}$ \\
\hline
\end{tabular}




\section{1 \\ 1.11. The volume of financial receipts to a special fund for international grants, projects in the total amount of financial receipts to a special fund based on the results of scientific and technological activities \\ 1.12. The volume of financial receipts to the specia fund on economic contracts (including international ones), in the total volume of financial receipts to the special fund based on the results of scientific and scientific and technical activities}

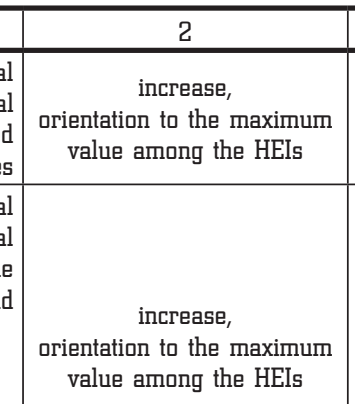

value among the HEIs

1.13. The number of HEI scientific publications, which are indexed by Scientometric databases Scopus and Web of Science

1.14. The volume of capital expenditures (from the general budget fund, from a special fund at the expense of foreign grants, from a special fund at the expense of sponsors and investors) to purchase equipment in the total amount of internal costs for the implementation of research and development

1.15. Number of scientific publications in the publications of the international databases 5copus or Web 1.16. The total h-index of the HEI

1.17. The number of objects of intellectual property rights that are registered by the HEI for the reporting period, based on the number of established 5SPWs

1.18. Number of objects of intellectual property rights obtained abroad, owned by the HEI of Science, based on the number of full-time 5SPWs

\section{Demonstrates the relevance of scientific research and the HEI recog-} nition at the international level, in particular among universities and academic institutions that are partners and co-executors of international projects and grants

Evidence of the level of HEI business activity. The high value of the indicator indicates the relevance of applied research, the correspondence of scientific developments to the needs of the real sector of the economy. The increase in the volume of financial receipts during a certain period of time indicates the quality, reliability and popularity of scientific and scientific and technical products. Positive dynamics of the value of the indicator confirms the business reputation and popularity of the HEI among customers of scientific and scientific and technical products (representatives of industry, business environment, government and local government, etc.)

\begin{tabular}{|l|l|} 
increase & $\begin{array}{l}\text { An indicator of the development level of the HEI scientific infra- } \\
\text { structure }\end{array}$ \\
\hline$>0$, & $\begin{array}{l}\text { Demonstrates the level of availability of modern instruments and } \\
\text { scientific equipment. Is one of the most important indicators of the } \\
\text { quality of scientific research }\end{array}$
\end{tabular}

\begin{tabular}{l|c|} 
& $\begin{array}{c}>0, \\
\text { increase }\end{array}$ \\
& \\
\hline $\begin{array}{l}\text { 1.19. The share of objects of intellectual property } \\
\text { rights, commercialized by a higher education estab- } \\
\text { lishment, in the total number of objects of intellectual } \\
\text { property rights that are registered by the HEI }\end{array}$ & $>0$, \\
\hline $\begin{array}{l}\text { 1.20. Presence of Quality Management System in } \\
\text { provision of services in the field of higher education, } \\
\text { scientific research and experimental development, } \\
\text { certified for compliance with the requirements of } \\
\text { DSTU I50 9001-2015 }\end{array}$ & \\
\hline
\end{tabular}

\section{2. "Training of scientific personnel of the highest qualification" subsystem}

\begin{tabular}{|c|c|c|}
\hline 2.1. Number of licensed postgraduate courses & increase & $\begin{array}{l}\text { Reflects the level of development of the scientific infrastructure. Demon- } \\
\text { strates the compliance of the scientific and pedagogical potential, informa- } \\
\text { tion and material and technical base with personnel and technological } \\
\text { requirements for material and technical, educational and methodological } \\
\text { and information support for the implementation of educational activities } \\
\text { in higher education in accordance with licensing conditions [26] }\end{array}$ \\
\hline 2.2. Number of doctoral specialties & increase & $\begin{array}{l}\text { A high value of the indicator that approaches or is equal to the maxi- } \\
\text { mum value among the HEIs is evidenced by the poly-vector nature } \\
\text { of the scientific topics in the HEI. According to [27], the condition for } \\
\text { the opening of doctoral studies is the presence of three full-time em- } \\
\text { ployees - doctors of science in relevant or related specialties; indicates } \\
\text { the availability of human resources, modern research, experimental } \\
\text { and material and technical base for the training of doctors of sciences }\end{array}$ \\
\hline $\begin{array}{l}\text { 2.3. Number of specialties on which theses are de- } \\
\text { fended in specialized scientific councils }\end{array}$ & $\begin{array}{l}\text { increase, } \\
\text { at least } 0.4 \text { of the number } \\
\text { of postgraduate specialties } \\
\text { in the HEI }\end{array}$ & $\begin{array}{l}\text { There is an indicator of the level of development of the HEI scientific } \\
\text { infrastructure. At present, the indicator is not informative, since specia- } \\
\text { lized academic councils are formed according to specialties in accordance } \\
\text { with the List of Scientific Specialties (List 2011), and doctoral and } \\
\text { postgraduate courses are opened and licensed in accordance with the } \\
\text { List of the branches of knowledge and specialties for which applicants } \\
\text { for higher education are trained List of 2015) [28] }\end{array}$ \\
\hline
\end{tabular}

Reflects the level of publication activity and scientific effectiveness of the SSPWs, as well as the level of fundamental and applied research

Shows the recognition level of the results of the HEI scientific activity. orientation to the maximum Summarizes information on the HEI scientific level

\begin{tabular}{|l|l|}
\hline $\begin{array}{c}>0, \\
\text { increase }\end{array}$ & $\begin{array}{l}\text { Reflects the S5PW innovative activity. } \\
\text { It is one of the criteria for granting and confirming the status of } \\
\text { national HEI [17] }\end{array}$ \\
\hline & $\begin{array}{l}\text { Low values of the indicator indicate that there is no possibility of } \\
\text { financing patenting in foreign countries. } \\
\text { Whe }\end{array}$
\end{tabular}

When diagnosing it is important to take into account that according to article 37 of the Law of Ukraine "On protection of rights to inventions and utility models», a person has the right to patent an invention in foreign countries provided that the application is submitted to the Ukrainian Patent Office. After this, if within 12 months there will be no objection from the department, it is possible to patent the invention abroad

Reflects the level of HEI innovative effectiveness.

It is one of the criteria for granting and confirming the status of national HEI [17]

Evidence of the implementation and operation of a quality management system in the HEI that meets the requirements and criteria of the international standard ISO 9000 . The availability of a certified system shows that all the main processes are manageable and HEI is competitive in the domestic and foreign markets of educational and scientific services

Beflects the level of development of the scientific infrastructure. Demonand information support for the implementation of educational activities mum value among the HEIs is evidenced by the poly-vector nature 作 and material and technical base for the training of doctors of sciences

There is an indicator of the level of development of the HEI scientific infrastructure. At present, the indicator is not informative, since specialized academic councils are formed according to specialties in accordance wostoraduate courses are opened and licensed in accordance with the for higher education are trained List of 2015) [28] value among the HEIs 
Continuation of Table 1

\begin{abstract}
1
2.4. The effectiveness of postgraduate studies (the proportion of graduate students who studied for state budget funds and completed post-graduate studies in the reporting year with the defense of a dissertation or presentation to a specialized academic council in the total number of postgraduates who studied for state budget funds and completed post-graduate studies in the reporting year)
\end{abstract}

2.5. The effectiveness of doctoral studies

\section{2}

Reflects the level of organization and control of the process of preparing doctors of philosophy (candidates of science) in the HEI. Demonstrates also the effectiveness of planning in the HEI in the formation of proposals submitted annually to the Ministry of Education and Science of Ukraine regarding the state order for the preparation of doctors of philosophy (candidates of sciences) through graduate school

\begin{tabular}{|c|c|c|}
\hline (⿻上丨 & [0.6-0.9] & $\begin{array}{l}\text { doctors of science in the HEI. There is an indicator of the planning } \\
\text { effectiveness in the HEI when formulating proposals that are submitted } \\
\text { to the Ministry of Education of Ukraine regarding the state order for } \\
\text { the preparation of doctors of sciences through doctoral studies }\end{array}$ \\
\hline $\begin{array}{l}\text { 2.6. The number of graduate students enrolled for the } \\
\text { funds of individuals and legal entities in the total num- } \\
\text { ber of graduate students enrolled in the reporting year }\end{array}$ & increase & $\begin{array}{l}\text { There is an indicator of the HEI reputation and credibility, as well as } \\
\text { the effectiveness of marketing activities }\end{array}$ \\
\hline $\begin{array}{l}\text { 2.7. The number of graduate students, completed } \\
\text { postgraduate studies in the current year, and remained } \\
\text { working in the HEI, in the calculation of the number } \\
\text { of graduate students, completed postgraduate studies } \\
\text { in the current year }\end{array}$ & [0.3-0.9] & $\begin{array}{l}\text { There is an indicator of the long-term interest of young scientists to } \\
\text { work in this particular HEI. Demonstrates the possibility of increasing } \\
\text { the proportion of highly qualified personnel in the total number of } \\
\text { scientific and scientific-pedagogical workers of the HEI }\end{array}$ \\
\hline $\begin{array}{l}\text { 2.8. The number of post-graduate students enrolled } \\
\text { in the reporting year in the total number of graduate } \\
\text { students enrolled in the reporting year }\end{array}$ & $\begin{array}{l}>0, \\
\text { increase }\end{array}$ & $\begin{array}{l}\text { Demonstrates the level of the HEI presence on the international market } \\
\text { of educational services, the attractiveness of the HEI for foreign citi- } \\
\text { zens - applicants for higher education. Demonstrates the availability } \\
\text { of adequate conditions for training, living, leisure }\end{array}$ \\
\hline $\begin{array}{l}\text { 2.9. The number of double diploma programs imple- } \\
\text { mented by the HEI jointly with foreign universities, } \\
\text { for applicants for higher education Ph.D. }\end{array}$ & $\begin{array}{l}>0, \\
\text { increase }\end{array}$ & $\begin{array}{l}\text { Reflects the availability of implemented modern educational technolo- } \\
\text { gies, the organization of the scientific and educational process and } \\
\text { a high level, in accordance with the standards and recommendations } \\
\text { for the quality assurance of higher education [29]. Demonstrates the } \\
\text { 55PW professional level }\end{array}$ \\
\hline $\begin{array}{l}\text { 2.10.The number of educational and scientific рго- } \\
\text { grams for the degree of Doctor of Philosophy in English }\end{array}$ & $\begin{array}{c}>0, \\
\text { increase }\end{array}$ & $\begin{array}{l}\text { Shows the availability of the necessary resources - personnel, informa- } \\
\text { tion - for the feasibility of educational and scientific programs in English }\end{array}$ \\
\hline $\begin{array}{l}\text { 2.11. The number of applicants for higher education in } \\
\text { the third (educational and scientific) level of the day-long } \\
\text { form of education during the reporting period studied } \\
\text { (internship) in foreign HEI (scientific institutions) in } \\
\text { the total number of post-graduate students of full-time }\end{array}$ & $\begin{array}{l}>0, \\
\text { increase }\end{array}$ & $\begin{array}{l}\text { There is an indicator of the HEI academic mobility level, as well as the } \\
\text { level of knowledge of foreign languages by the candidates for higher } \\
\text { education of the third (educational-scientific) level }\end{array}$ \\
\hline
\end{tabular}

\section{3. «Ensuring the creative activity of participants in the educational process» subsystem}

3.1. The number of full-time students involved in scientific research, in the calculation of the total number of full-time students
Shows the level of organization of scientific work with students in the HEI. When forming the indicator, such types of student's scientific work during extra-curricular time are taken into account:

- participation in the implementation of state budget and research contracts, international grants;

- participation in inventive activities;

$\geq 0.25$, increase $\quad$ - work in student design bureaus;

- work in scientific societies and circles, problem groups;

- participation in scientific conferences and competitions.

Participation of students in research work contributes to the in-depth assimilation of educational disciplines, systematization and generalization of the acquired knowledge, the formation of abilities to apply theoretical knowledge in practice, the development of independent work skills There is an integrated indicator of the students' level of achievement.

3.2. The number of full-time students received scholarships from the President of Ukraine, who became the winners of All-Ukrainian and international competitions of student scientific works, in the calculation of the total number of full-time students

3.3. The number of scientific works published by students in professional publications and publications is indexed by international databases, in the calculation of the total number of full-time students

$>0$,
increase

increase

\section{4. "Use of the results in the educational process" subsystem}

4.1. Number of issued textbooks, teaching aids, in calculating the number of staff units of scientific and pedagogical workers
Demonstrates the level of effectiveness of the system of internal quality assurance of higher education

Demonstrates the level of scientific activity of students, the assimilation of scientific theories and concepts, the acquisition of the necessary competencies (the skills of systematization and generalization of the acquired knowledge, the ability to apply theoretical knowledge in practice, etc.), as well as the systematic work of scientific and pedagogical workers with students

\begin{tabular}{|c|c|}
\hline & increase \\
\hline
\end{tabular}

Testifies to the improvement of the level of the provision of the educational process with educational and methodical publications, the introduction of scientific developments of teachers in the educational process, as an indispensable condition for the preparation of competitive specialists. Demonstrates the availability of opportunities to familiarize students with the main trends and achievements of science and technology in the chosen field 


\begin{tabular}{|l|c|l|}
\hline 1 & 2 & 3 \\
\hline $\begin{array}{l}\text { 4.2. Number of issued monographs recommended by } \\
\text { the Academic Council of the HEI in calculating the num- } \\
\text { ber of staff units of scientific and pedagogical workers }\end{array}$ & increase & $\begin{array}{l}\text { Demonstrates the availability of opportunities to familiarize students } \\
\text { with the current trends in the development of science and technology. } \\
\text { Evidence of the level of scientific activity and effectiveness of scientific } \\
\text { and pedagogical workers }\end{array}$ \\
\hline $\begin{array}{l}\text { 4.3. The number of foreign teachers and scientists } \\
\text { who took part in the training process on the basis of } \\
\text { the labor agreement, calculated as a percentage of the } \\
\text { total number of staff members of the 5SPW }\end{array}$ & $\begin{array}{l}\text { Testifies to the availability of opportunities for the formation among } \\
\text { students of values that are traditional for the global academic and } \\
\text { scientific environment. Demonstrates the attractiveness and popularity } \\
\text { of HEI from foreign HEIs }\end{array}$ \\
\hline
\end{tabular}

Note: ${ }^{*}$ formed by the authors.

It is also important to note that in order to obtain adequate and more valid data for the evaluation of the HEI scientific activity, the list of «Indicators of scientific and technical activities of the HEI» should be clarified, supplemented, in particular, with indicators such as:

- «The number of full-time SSPWs, at least three months during the reporting period or with the completion of an internship in the reporting period, conducted training sessions in foreign HEI (scientific institutions)»; - «The number of full-time SSPWs and doctoral candidates who are certified in accordance with the Common European Recommendation on Language Education at a level no lower than B2, from the languages of the countries of the European Union, confirmed by TOEFL tests, the International English Language Testing System or the Cambridge Certificate English Language Assessment (English), Goethe-Zertifikat, TestDaF (German) DELF or DALF (French) and DELE (Spanish)»;

- «The number of scientific journals included with a non-zero coefficient of influence in the databases Scopus, Web of Science, other scientometric databases recognized by the MES, issued by the HEI»;

- «The number of conferences and symposiums organized and held in the HEI, the materials of which are indexed by Scopus or Web of Science»;

- «The number of foreign teachers and scientists who participated in the training process on the basis of a labor agreement»;

- «The number of scientific and scientific-pedagogical workers of the HEI who are members of the editorial boards of scientific journals included in Scopus or the Web of Science are reviewers of such journals».

Some of these indicators are planned to be displayed in the monitoring mission of the national HEI in support of the national status and posted on the official website of the National Agency for Quality Assurance in Higher Education). However, for the current diagnosis, information on these indicators is important to analyze every year.

Diagnosis of the state of the system of scientific activity on the proposed indicators can be used both for internal diagnostics (self-diagnostics) of the HEI, and for external rapid diagnostics of the HEI scientific activity.

\section{SWOT analysis of research results}

Strengths. The strength of this research is the possibility of a sound analytical evaluation of the main aspects of the HEI scientific activity system.

Weaknesses. The weakness of this research is the absence of indicators that would provide an opportunity to assess the quality of scientific research, and in some cases the adequacy of the selected criteria for the essence of a certain process. For example, the indicator «The volume of capital expenditures for the purchase of equipment in the total amount of internal costs for the implementation of research and development», indicates the fact of the financial costs of acquiring equipment, but does not characterize what equipment was purchased.

Opportunities. Opportunities for further research are the use of selected indicators for diagnosing the scientific activities of specific HEIs, their improvement in the diagnostic process, and the expansion of the list of indicators for fundamental diagnosis.

Threats. The threat to the results of the conducted research is the problem of the transition from specific indicators and indicators to the general ideas about the HEI scientific activity system during the diagnosis.

\section{Conclusions}

1. As a result of the conducted studies, a clear indicator base for diagnosing the state of the HEI scientific activity system behind such subsystems is formed:

- conducting of scientific research;

- training of highly qualified scientific personnel;

- ensuring the creative activity of participants in the

educational process;

- use of the results in the educational process.

Interpretation of results, monitoring and assessment of the state of the scientific activity system on the proposed indicators will allow to form an information array of data on existing problems, potential threats and risks in the field of scientific activity. And also in the future - to develop proposals to eliminate these problems, to prevent threats and risks.

2. Proposals have been formulated to supplement the forms of «Indicators of scientific and technical activities of the HEI» with additional indicators, in particular, on the level of SSPW qualifications and the HEI scientific infrastructure, which provide more valid data for diagnosing the HEI scientific activity.

\section{References}

1. Grechan A. P., Radionova N. Yo. Diagnosis of the efficiency of enterprises // Bulletin of the Volodymyr Dahl East Ukrainian National University. 2011. Vol. 10, No. 1. P. 13-17.

2. Melnyk O. G. Systems of diagnostics of activity of machinebuilding enterprises: polycrystalline concept and toolkit: monograph. Lviv: Publishing House of Lviv Polytechnic National University, 2010. 344 p.

3. Zhuk L. Basic Principles of Scientific Research in Higher Education Institutions: Management and Financing // Economics, Entrepreneurship, Management. 2017. Vol. 4, No. 1. P. 1-14. doi:10.23939/eem2017.01.001 
4. Kuzmin O., Yastrybskyy M. Implementation of the higher education prospective development concept: Ukrainian reality and experience of the countries of East Asia: monograph. Goslar: LAP Lambert Academic Publishing, 2017. 50 p.

5. Markusova V. A. Who and how measures science? // Alma mater. 2002. Vol. 12. P. 42-46.

6. Pisliakov V. V. Methods of academic degree evaluation by citation index // Sociological journal. 2007. Vol. 1. P. 128-140.

7. Vagin V. N., Oskin P. V. Heuristic and stochastic methods of reading effective values in diagnostic systems // Bulletin of the Russian Academy of Sciences. Theory and systems of management. 2006. Vol. 4. P. 78-93

8. Vyborova Ye. N. Economic diagnostics in the system of business entity management: monograph. Novosibirsk: Sib. UPK, 2007. 251 p.

9. Rousseau R. Journal evaluation: technical and practical issues // Library Trends. 2002. Vol. 50, No. 3. P. 418-439.

10. Feshchur R. V., Samulyak V. Yu. Groups of indicators for assessing the level of enterprise's development // Bulletin of the Lviv Polytechnic National University. Series: Management and Entrepreneurship in Ukraine: Stages of Development and Development Issues. 2010. Vol. 691. P. 231-239.

11. Melnyk O. G. Diagnostics of the activity of the machinebuilding enterprise on the basis of the system of economic indicators: monograph. Lviv: Ukrpol, 2009. 188 p.

12. Kaplan R. S., Norton D. P. Balanced Scorecard. From strategy to action. Moscow: Olympus Business, 2003. 304 p.

13. Kaplan R. S., Norton D. P. Strategic unity: creating synergy with the help of balanced indicator system. Moscow: Williams ID, 2006. $384 \mathrm{p}$

14. Diagnostics of the production systems / ed. by Anuapu F. F. Irkutsk: ITSNTI, 1972. $39 \mathrm{p}$

15. Mitsenko N. G., Kulay S. M. Diagnosis of the state of economic activity of the enterprise // Scientific bulletin of Ukrainian National Forestry University. 2010. Vol. 20.5. P. 223-227.

16. Ananyshnev V. M., Tkachenko A. V., Fursov V. V. The international criteria and indicators for assessing university activities // System Psychology and Sociology. 2016. Vol. 19. P. 86-92. URL: http://systempsychology.ru/journal/2016_19/354-v-mananishnev-a-v-tkachenko-v-v-fursov-mezhdunarodnye-kriterii-i-pokazateli-ocenki-deyatelnosti-vuzov.html (Last accessed: 26.01.2018)

17. On Approval of the Procedure and Criteria for Granting a National Status to an Institution of Higher Education, confirmation or deprivation of this status: Resolution of the Cabinet of Ministers of Ukraine No. 912 from November 22, 2017 // Legislation of Ukraine. URL: http://zakon3.rada.gov.ua/laws/ show/912-2017-\%D0\%BF (Last accessed: 26.01.2018).

18. Public discussion of the project of Decree of the Cabinet of Ministers of Ukraine «On Approval of the Procedure for Conducting State Certification of Institutions of Higher Educational in Relation to Their Scientific (Scientific and Technical) Activity» // Ministry of Education and Science of Ukraine. June 23, 2017. URL: https:// mon.gov.ua/ua/news/gromadske-obgovorennya-proektu-postanovikabinetu-ministrv-ukrayini-pro-zatverdzhennya-poryadku-provedennya-derzhavnoyi-atestaciyi-vishih-navchalnih-zakladiv-u-chastini-provadzhennya-nimi-naukovoyi-naukovo-tehnichnoyi-diyalnosti (Last accessed: 26.01.2018)

19. Ananyshnev V. M. Management Sociology: monograph. Moscow: Engineer, 2008. 267 p.

20. On approval of the form of state statistical observation No. 3-science (annual) «Report on the implementation of scientific research and development»// State Service of Statistics of Ukraine. 2016. No. 104. URL: http://ukrstat.gov.ua/norm doc/2016/104/104_2016.htm (Last accessed: 26.01.2018).

21. On approval of the form of state statistical observation No. 1-nk (annual) «Report on the work of post-graduate and doctora studies» // State Service of Statistics of Ukraine. 2017. No. 191. URL: http://www.ukrstat.gov.ua/norm_doc/2017/191/191_2017. htm (Last accessed: 26.01.2018).
22. On approval of the forms of state statistical observation No. 1-PV (monthly) and No. 1-PV (quarterly) «Labor report»// State Service of Statistics of Ukraine. 2016. No. 90. URL: http:/ ukrstat.gov.ua/norm doc/2016/90/90 2016.htm (Last accessed: 26.01.2018)

23. On the results of scientific and technical activities // Ministry of Education and Science of Ukraine. 2017. No. 1609. URL: https://mon.rit.org.ua/info/nakaz 2017-12-13 1609.pdf (Last accessed: 26.01.2018)

24. Suganyaka M. V. Structural-logical model of calculation of the integral index of anti-crisis stability of the system bank // Effective economy. 2012. No. 7. URL: http://nbuv.gov.ua/UJRN/ efek_2012_7_6 (Last accessed: 26.01.2018).

25. Law of Ukraine on Higher Education No. 1556-VII from July 1 , 2014 / Cabinet of Ministers of Ukraine // News from the Verkhovna Rada. 2014. No. 37-38. P. 2004. URL: http://zakon0. rada.gov.ua/laws/show/1556-18 (Last accessed: 26.01.2018).

26. On Approval of Licensing Conditions for Educational Activities of Educational Institutions: Resolution of the Cabinet of Ministers of Ukraine No. 1187 from December 30, 2015 // Legislation of Ukraine. URL: http://zakon3.rada.gov.ua/laws/ show/1187-2015-\%D0\%BF (Last accessed: 26.01.2018).

27. On Approval of the Procedure for Preparing Graduates of Higher Education in the Degree of Doctor of Philosophy and Doctor of Science in the Institutions of Higher Educational (Scientific Institutions): Resolution of the Cabinet of Ministers of Ukraine No. 261 from March 23, 2016 // Legislation of Ukraine. URL: http://zakon3.rada.gov.ua/laws/show/261-2016$\%$ D0\%BF (Last accessed: 26.01.2018).

28. On Approval of the List of Fields of Knowledge and Specialties under which Graduates of Higher Education are Prepared Resolution of the Cabinet of Ministers of Ukraine No. 266 from April 29, 2015 // Legislation of Ukraine. URL: http:// zakon2.rada.gov.ua/laws/show/266-2015-\%D0\%BF (Last accessed: 26.01.2018).

29. Standards and Guidelines for Quality Assurance in the European Higher Education Area (ESG). Ministerial Conference in Yerevan. May 14-15, 2015. 32 p. URL: http://www.britishcouncil. org.ua/sites/default/files/standards-and-guidelines_for_qa_in_ the ehea 2015.pdf (Last accessed: 26.01.2018).

\section{ФОРМИРОВАНИЕ ИНДИКАТОРНОЙ БАЗЫ ДИАГКОСТИКИ СИСТЕМЫ НАУЧНОЙ ДЕЯТЕЛЬНОСТИ УНИВЕРСИТЕТА}

Предложено и обосновано совокупность индикаторов для диагностирования состояния системы научной деятельности высших учебных заведений. Все индикаторы сгруппированы по подсистемам, которые отражают важнейшие направления научной деятельности. Показано, что наиболее репрезентативными индикаторами являются показатели ресурсного обеспечения научной деятельности, ее результативности, а также показатели, характеризующие устойчивость, адаптивность и надежность системы. Для каждого из выбранных индикаторов установлено нормативно-критериальные значения.

Ключевые слова: диагностика состояния системы научной деятельности университета, индикаторы для диагностирования, высшие учебные заведения.

Kuzmin Oleh, Doctor of Economic Sciences, Professor, Director of the Institute of Economics and Management, Lviv Polytechnic National University,Ukraine, e-mail: oleh.y.kuzmin@lpnu.ua, ORCID: https://orcid.org/0000-0002-6014-6437

Melnyk Olha, Doctor of Economic Sciences, Professor, Head of the Department of Foreign Trade and Customs, Institute of Economics and Management, Lviv Polytechnic National University, Ukraine, e-mail: olga.g.melnyk@lpnu.ua, ORCID: https://orcid.org/00000001-8819-1910

Zhuk Liliya, PhD, Associate Professor, Head of Scientific Research Department, Lviv Polytechnic National University, Ukraine, e-mail: liliia.v.zhuk@lpnu.ua, ORCID: https://orcid.org/0000-00017299-2705 